\title{
Animal Mistreatment in Business: Ethical Challenges and Solutions
}

\author{
Yuanfang Wang ${ }^{1}$, Peng Chan ${ }^{2}$ \\ ${ }^{1}$ University of the West, Rosemead, USA \\ ${ }^{2}$ California State University, Fullerton, USA \\ Correspondence: Peng Chan, Department of Management, California State University, Fullerton, CA 92604, \\ USA.
}

Received: March 23, 2017

Accepted: April 10, $2017 \quad$ Online Published: April 24, 2017

doi:10.5539/ibr.v10n5p159

URL: https://doi.org/10.5539/ibr.v10n5p159

\begin{abstract}
Animal mistreatment in businesses around the world is becoming a hotly debated topic. Many animal welfare laws protect wild animals and pets, but make exemptions for animals in farms, zoos or labs. There are economic benefits behind animal mistreatment since businesses can maximize profits by, for example, raising animals in crowded spaces, or forcing them to perform shows. However, ethical arguments on this issue reveal that animal mistreatment may actually cost more than humane animal treatment. Furthermore, consumer awareness on animal mistreatments is increasing, so this poses both a threat and opportunity to businesses. As society puts more and more value on sustainable green business today, inhumane animal treatments may harm a company's reputation and reduce its sales. Businesses should be aware of this trend and examine new humane alternatives to their traditional practices in order to stay competitive in the market.
\end{abstract}

Keywords: animal abuse, business ethics, corporate social responsibility, environmental sustainability

\section{Introduction}

Animals have been human's companions for thousands of years. They serve as people's food, medicine, transportation, farming labor, and entertainment. However, the rise of commercialism has forced businesses to maximize profit which means reducing cost while increasing production on animal products and services. This trend has led to a series of industrialized inhumane treatment of animals, such as slaughter at early age, captivity, stressful living condition(page number required for direct quotation).s, overuse of antibiotics and drug testing. If animal rights are important ethical topics, businesses cannot ignore this topic, for example, the 68 billion animals slaughtered every year in farms. In addition, livestock is responsible for emitting $64 \%$ of anthropogenic ammonia, which holds a severe potential for ecosystem pollution (Zur \& Klöckner, 2014). Thus, factory farming alone contributes substantially to environmental unsustainability, let alone many other types of businesses that are guilty of animal abuse.

Like humans, many animals have a sense of pain and emotion. "Certain species are capable of complex emotions, can communicate using language, and have a sense of self" (Hitch, 2015). Therefore animal welfare becomes an issue of business ethics. Abusive actions are not acceptable for many animal-rights activists, but businesses may argue that it is required for them to survive and serve the market demand. Are animal mistreatments necessary for business' profitability? What are the solutions for animal mistreatment in business?

This paper examines current animal mistreatments in business practices, including those in agriculture, entertainment, laboratory research and pet breeding. Next, the paper explores related laws and regulations, economical reasoning behind animal welfare, and arguments on animal rights. The analysis focuses on solutions to reduce and prevent animal mistreatments, and highlights managerial implications on this topic of animal welfare in businesses.

\section{Animal Abuse in Business}

\subsection{Agriculture}

Throughout history, humans have used animals for food and labor in agriculture. In modern times, farming labor has largely been replaced by machines. In this section we focus on animal mistreatment in the production of animal products: meat, eggs and milk. According to Farm Forward (2010) although there are still animal-friendly ranches around, cruel "factory farms" produce $99 \%$ or more animal flesh in order to satisfy the food demand in 
the United States (Farm Forward, 2010). Factory farms, by its name, aim to produce animals as commodity products based on economies of scale. As profit-driven companies, their top consideration is efficiency of production, not animal welfare.

Animals in industrialized factories often live in crowded confinements, away from their natural habitats. Their living conditions are often filthy, unconformable and stressed. Antibiotics are frequently used in animal feed to "combat immunological stress from overcrowding and production-associated diseases...and to promote faster weight gain" (Rossi \&Garner, 2014). Taking beef cattle as an example, many of them have never seen grass, because they are being fed by high-protein soybeans so that they can gain weight faster. The farm is full of foul smell from cow waste. As soon as the animal reaches market weight, it will be slaughtered for sale. The average lifespan of beef cattle is 2 years, compared to their natural lifespan of 20 years (Saja, 2013).

For egg production, abusive practices of chicken start as soon as chicks are hatched. Immediately after hatching, the male and female chicks are separated. Females will be sent to egg production facilities and the males are destroyed (Farm Forward, 2010). "Destroy" means the male chicks are killed in the first day of their lives, because they do not lay eggs. Females are not any luckier, as they must endure a long period of torture. Female chickens live in small cages of a size of printer paper where they can hardly open their wings or turn around for their entire lives. They suffer serious stress and $80-89 \%$ of hens have osteoporosis due to forced heavy egg production (Greger, 2011).

Milk production involves heavy animal mistreatment as well. Cows do not produce milk unless they give birth to calves, so they will be artificially inseminated to pregnancy. The baby calf is taken away by force from the mother immediately after birth, because the mother's milk needs to be reserved for human (Macwilliams, 2013). A male calf will be made into veal meat, and a female calf will be raised to become another dairy cow. A dairy cow only lives for 4 years compared to their natural lifespan of 20 years (Saja, 2013). As their milk production drops to a point that it is no longer favorable for the business, the cow usually will be slaughtered for hamburger meat.

Animals living in factory farms certainly suffer from crowded, dirty and stressful surroundings, use of constant antibiotics, and substantially shortened lifespan. Often times, these mistreatments are accompanied by emotional distress of losing freedom or losing their kids. Agriculture is definitely a major industry for animal immoral actions.

\subsection{Entertainment}

Besides being people's food, animals also play a substantial role in providing entertainment to human beings. Examples are monkeys at zoos and circus, elephants picking up children for money at tourist sites, dolphins performing shows, and horses for riding and competition. These animals are better off compared to farm animals because the entertainment business does not directly kill them, but a lifetime of slavery, captivity, and stress are major concerns.

Famous animal theme park Sea World was heavily criticized for cruelty on orca whales ("killer whales"). In 2013, a famous documentary called "Blackfish" revealed the stunning truth behind orca whale performance and accused Seal World for conducting animal abuse (Goodale, 2015). Original orca whales were captured from the wild four decades ago and the breeding program sustains the need for the park in later years. Orca whales are selected for mates in the nature, but have to receive regular artificial insemination at Sea World. Besides, the tank for the whales are too small and too shallow that they often develop sunburn scars, and they have to swim over a thousand circles around the pool per day to get enough exercise. Orca whales are highly intelligent and social creatures. In the wild they stay in groups led by a "matriarch", with her baby calves, her older young calves and her adult calves (Last, 2012). They even have a "babysitting system" to share the responsibility of taking care of the calves. Captivity deteriorates these smart animals' mental and physical health at a stunning rate. A killer whale in captivity is 2.5 times more likely to die compared to a wild killer whale (Last, 2012).

The case of the orca whale reflects ethical problems from animals used for human entertainment: captivity, bad living conditions, psychological stress and so on. Animals in circuses, at tourist sites, and in the zoos all suffer from mistreatments similar to orca whales (Shani, 2010). On the one hand, close interaction with live animals do provide value for education, and zoos can protect endangered species. One the other hand, torturing animals either mentally or physically just to make profits is not considered moral. There are a few zoos that do contribute to human's knowledge of nature, but the majority of zoos are still "morally unjustified" (Shani, 2010).

\subsection{Laboratory Experiments}

Animals are often used for experiments to test a new drug, new chemical, new vaccine, new food or skin-care 
product. The lab practices may lead to itching, allergies, pain, tumor, insomnia and death for these animals. $90 \%$ of animals in laboratory testing are mice and rats (Badyal, 2014), but people also use birds, rabbits, pigs, hamsters, and even human's relative -- chimpanzees. In the US, more than 100 million animals have died due to laboratory experiments (Collins, 2015). Collins also points out that before these animals die, they have to sometimes inhale toxic smoke, have their skull opened, have their skin burned, be restricted to move...etc. Lab environment is stressful and uninhabitable for these caged animals to be healthy, and it is not an ethical practice to torture helpless animals for our own benefit and curiosity. After all, animals in labs do not have better lives compared to those in farms and in zoos.

\subsection{Pet Breeding}

Pet breeders may look like they are very nice to animals and many of them do love pets. However, some research shows that the pet breeding business is also questionable in terms of ethics. Pet breeding is, after all, still a business that aims for profit. Breeders focus on purebred and they look for animals that can be sold at a high price, not the happiness of animals at large. The criticism of pet breeding targets the fact that there are already too many unsold pets, yet pet breeders are creating more lives irresponsibly. Every dog or cat purchased from a breeder is a sign for the euthanization of a homeless pet in the shelter, due to a missed chance of finding a new home (PETA, n/a).

A second criticism on pet breeding is that it intervenes against evolution and creates certain traits on animals which human desires. These traits may be harmful for animals and not functional for them. The birth defects coming from breeding can include "crippling hip dysplasia, blindness, deafness, heart defects, skin problems, and epilepsy" (PETA, n/a). Even for those pets who successfully survive, the looks humans want may not be beneficial to them: e.g. a short face that is difficult for breathing, overly long hair that covers their sights, or a mouth that keeps dropping saliva.

Above are four common categories of businesses that are directly involved in animal mistreatment. However, there are more industries that kill and harm animals indirectly (e.g. from polluting the natural environment). Since the indirect harm to animals is too large a topic to be explored, this paper will focus on the above four types of businesses. The questions facing these cruel practices are: can businesses still operate ethically when there are known animals suffering? Are there solutions to end animal cruelty while keeping the businesses running? To answer these questions, we will first examine current laws and regulations on animal welfare and their efficiency, followed by economic reasoning behind current unethical animal treatment in businesses and opposing perspectives on animal welfare.

\section{Laws and Regulations on Animal Welfare}

There are already many laws and regulations that try to protect animal rights, especially in developed countries. A famous one is "Animal Welfare Act" which was established in 1966 in the US, followed by a series of amendments all the way up to 2013. The Act regulates that animal deals, exhibitors, transporters and researchers must be registered or licensed, and a license will be issued only if the party meets the compliance requirements (Animal Welfare Act, 2016). However, farm animals and pets in trade shows and pet stores are exempt from the Act. In addition, "rats and mice, along with birds bred for experimental purposes, are exempt from the requirements of the Animal Welfare Act" (Kuwahara, 2011). Therefore the US Animal Welfare Act does not protect all animals.

Animal mistreatment can be difficult to prosecute as well. During 2011-2012 the Agri-Food \& Veterinary Authority of Singapore investigated 444 alleged cruelty complaints of which only 2 offenders were prosecuted (See, 2013). So there is a big gap between filed complaints and the cases that actually got prosecuted. Singapore has the Animals and Birds Act but, unfortunately, animals for food, entertainment, and research are excluded from the animal protection laws just like in US. When processing an animal abuse case, the court must first determine if the action towards to the animal is legitimate, but the list of 'legitimate' uses of animals is 'virtually endless' (See, 2013). Animals in zoos, labs, farms do not receive protection from law.

Similarly, Northern Europe has regulations on farm animals, but only to label them differently based on how much animal welfare the farm provides to animals, like "free-range" or "organic". Compliance with higher animal welfare standards is a choice for businesses, not a requirement (Heerwagen et al, 2015). However, the labeling will only largely improve animal welfare if customers eagerly support it. In the Danish market, the market share of products with "quality labels" is around15\% (Heerwagen et al, 2015). This small number shows low level of interests for the general public to purchase meat from an animal-friendly farm. Thus, the labeling legislation only has a moderate impact on reducing animal cruelty, but at least this is a good step forward to encourage animal-friendly practices. 
Other smaller-scale legislations are also in effect. In 2015, California's Prevention of Farm Animal Cruelty Act and its corresponding Assembly Bill (AB) 1437 eliminated "battery cages" for hens in California (Malone, 2016). This act also requires farms to give hens at least 116 square inches of floor space (Malone, 2016). It is a victory for animal welfare activists who also have lobbyists working hard to make this bill pass. However, 116 sq. in. is similar in size to two sheets of letter-sized paper. This tight space, even without cages, is still much less than what the birds naturally desires for a healthy life. Cage-free systems are not better animal welfare (Kesmodel, 2015). They do not really save the birds but increase the price of eggs.

\section{Economic Reasoning for Animal Mistreatment}

\subsection{Reduce Cost \& Maximize Profit}

A major reason behind inhumane animal treatment is that it reduces production costs substantially. Take poultry production as an example: why do chickens have to live in cramped spaces? This is because tight spacing limits their activities so that they can gain maximum weight. Research shows that "successful and profitable fattening of broiler chickens could be arranged in population density between 14 and 15, and 16 birds per square meter (10.8 square feet). In this case, the production results would be between 33 and $35 \mathrm{~kg} / \mathrm{m} 2$ meat (Mitrovic, et al. 2010). Another business concern is that the factory farm only have limited space and purchasing new facilities can be costly. Therefore producing as much meat as possible in limited space is favored.

A second example comes from beef and milk production. Why do factory farms slaughter cattle at an early age (for beef cattle at age 2 and for dairy cows at age 4-5)? This is because when they get older, keeping them won't be economically efficient as they will produce less while eating the same amount of feed. A study has reported that in cattle (for milk and for reproduction), maximum production (measured by weight of calf at weaning) does not peak until 5 years of age (Durham, 2011). After it peaks, their productivity drops and it is no longer profitable for factory farm owners to keep them alive. Similar cost-reducing mindset also lies in animal laboratory experiments, where purchasing mice is much cheaper than human testing or simulation software development.

\subsection{Improve Quality}

Think about will a drug that has not been tested on animals before it is considered safe by patients and gaining federal approval for sale? Because animal experiment signals safety, research institutions usually exaggerate their results from animal testing (Collins, 2015). Similarly, in the pet breeding business, customers love pure breeds and young, good looking pets. Pets from a breeding company may give the impression of good gene selection and high quality. No matter if the "quality" is really good or not, businesses have an economic reason to mistreat animals if this can lead to better image and therefore higher profit potential.

\subsection{Only Factory Farms can Meet Market Demand}

Global market demand for meat consumption is rising. A person consumes on average of $89 \mathrm{~kg}$ (191 lbs.) of meat per year when his or her annual income is US\$43,901. China has the highest growth rate of $5.1 \%$ per year in meat consumption, followed by India and Brazil. Even developed countries, like Norway, has an annual growth rate of $1.6 \%$ (Cole \& McCoskey, 2013). Given such high meat demand, how can businesses satisfy the market if they do not pursue low-cost and conventional high-volume factory farming? This is often a question posed to animal welfare activists.

While it may be true that only highly efficient factory farms can satisfy the market demand, the negative externalities of meat consumption must be examined first to see if people really want to satisfy the demand or lower the demand. Farming animals is one of the top threats to environmental sustainability. Meat production contributes about $51 \%$ of all greenhouse gas emission globally, exceeding the emission from all the transportation vehicles added up together in the world (Cole \& McCoskey, 2013). In the US, livestock contributes to $80 \%$ of surface water contamination. Human also lose 40 billion tons of soil per year due to erosions caused by animal products production. Furthermore, the livestock sector accounts for about 78 per cent of all agricultural land, and 30 per cent of the land surface of the planet (Zur \& Klöckner, 2014). Counting these environmental costs, meat price would increase to a level where most people cannot afford to eat regularly.

Meat consumption also deprives us of natural resources. Meat is the most expensive source of food, as it takes 6 pounds of high-quality grain to produce 1 pound of meat (Hoovers, 2011). If all the grain for livestock in the US is used to feed humans, then 800 million more people can be fed (Cole \& McCoskey, 2013). As there are people still starving on earth, eating meat means taking food away from them and leads to waste of natural resources that produces these grains.

The damage on the environment from meat production is so severe that it becomes a global threat facing society. 
As Cole and McCoskey (2013) argued, "demand for meat may require aggressive and potentially controversial policy interventions" in order to protect our planet. Therefore it is not a problem of meeting meat demand, but more a problem of reducing the meat demand. If factory farms continue to run as they are, there will be perpetual devastation to our environmental sustainability and not only animals but also human beings may not have an inhabitable earth in the future.

However, before we can conclude that reducing meat demand is the key to reducing animal mistreatment, there is an important question for us to answer: will humans gain enough nutrition by eating less or no meat? In the last 100 years human consumption of animal products exploded and there have been more people with obesity, heart diseases and high cholesterol. The relationship between over-consumption of animal protein and these diseases are clear according to researchers: more animal protein consumption is positively correlated with cholesterol levels, and the lower the percentage of animal-based foods that are consumed the greater the health benefits (Green et al, 2010). Green's study indicates that a healthy level of animal-based diet shall be 0-10\% of total calorie intake. Therefore, people are eating too much animal protein than they should and reducing the demand for meat can actually benefit human health.

In summary, businesses do not have an ethical excuse of "meeting the demand" to mistreat animals in producing animal products, because the demand is already so high that it deteriorates our environment, our natural resources and also people's health. "Meeting the demand" may itself become unethical. Rather, if animal-friendly farming practices cannot meet market demand due to inefficiency, then increased prices may adjust the market balance accordingly by discouraging an animal-based diet, thus benefiting the environment and our health.

\subsection{Zoos Contribute to Species Preservation}

Due to climate change and human activities, many wild animals suffer from habitat loss and become endangered. One argument supporting animal confinement in zoos is that it contributes to species preservation: "if a species is likely to become extinct in the wild and you can capture the animals humanely and recreate the physical and behavioral conditions...then that function of zoos is defensible" (Keulartz, 2015).However, zoos do not always have endangered species, and they keep many animals for human amusement and entertainment. Even for endangered animals, confinement may lead to a loss of wild abilities and the animal may not be released to live independently again. It is impossible for any zoo to recreate an environment that is truly comparable to animals' natural habitats because it requires immersive spaces (Keulartz, 2015). Does the benefit of species preservation outweigh the liberty and well-being of animals? It remains a controversial question.

\subsection{Animal Testing Is Required for Biological Product Development}

As discussed earlier, animal testing may suggest product safety and quality in biological products like medicine. Moreover, when human testing is considered high-risk, regulating agencies encourage experiments on animals. In 2002, the US Food and Drug Administration (FDA) published "Animal Rule" which establishes "approval of drug and biological products for human use whereby researchers can use animal data and not have to show efficacy in human subjects" (Walker, 2011). FDA's movement is to protect human subjects who may be exposed to harmful ingredients during the test, and it does not waive the testing requirement either. The hidden assumptions here are (1) a new biological product is safer if it has been tested on living beings, and (2) the results from animal experiments can well predict reactions on human.

However, these assumptions are questionable. The safety of a biological product depends on many aspects including design of the product and the manufacturing processes. As one study found, "testing product and process intermediates alone is helpful, but does not provide a complete solution to viral safety" (Plavsic, 2016). Secondly, animal experiment results cannot always indicate the product's effectiveness on humans. As a former director of US National Cancer Institute noted, scientists have cured cancer on mice decades ago, but the cure could not work on humans (Collins, 2015). Human diseases are best studied if people can focus on humans, and people should not sacrifice animals simply because humans do not want to take the risk. Therefore, the testing requirement of biological products is not a strong ethical excuse for animal mistreatment.

\section{Possible Solutions}

\subsection{Alternatives to Factory Farming}

The simplest way to reduce animal suffering in factory farming is vegetarianism as it reduces the demand of meat and thus reduces the numbers of animals being raised and killed. However, not everyone on earth can easily become a vegetarian. The taste and nutrition people desire from animal-based food is still valued in our society. According to the Food and Agricultural Association of the United Nations, India is the country with the highest 
number of vegetarians, but they account for only $42 \%$ of households (Sarkar, 2014). Vegetarianism is likely to reduce animal cruelty, but may not eliminate it due to global differences in tastes and diets.

Another alternative is to promote animal friendly farms which allow cattle to graze on pastures and chickens to run around. A humane farm will not feed the animals with hormones and antibiotics unnecessarily and will provide them with a natural habitat. The animals can live close to their live expectancy with happy mood. When they have to be slaughtered, farms can use painless methods like carbon dioxide gas intoxication. In summary, animals in humane farms "do not experience pain, distress, injuries, frustration, disease, hunger, or thirst" and their natural needs are met (Vaarst, 2012). However, the success of these farms does require humans to reduce animal-based product consumption first, because humane farms have low productivity in producing meat, egg, milk or other animal products. For example, "available pasture on the earth could not sustain the 1.3 billion cattle now raised and slaughtered for food" (Pluhar, 2010). We simply do not have enough natural resources to provide to these animals.

In addition, animal activists contend that it is never moral to kill lives for food, no matter how humanely animals are treated: "It would be wrong to raise succulent young humans for their flesh...same applies to sentient nonhumans" (Pluhar, 2010). Humane farms are still unethical according to these activists. Therefore, combined with the promotion of vegetarianism and education which will be discussed later, customers may be willing to consume less animal products or pay more for them. Then, turning factory farms into animal-friendly farms could be a practical and favorable solution for animal mistreatment. However, ethical issues may not be fully avoided.

A new innovative solution for factory farm cruelty is In-Vitro meat, which is meat cultured in labs without killing a life. This production process involves extracting cells from a live animal, then culture the cells in "nutrient-rich growth medium in a bioreactor" to form muscle (Laestadius, 2015). In-Vitro meat is not on the market for sale yet, but controversy has already shrouded this new technology. Supporters state that cultured meat is healthy with no negative environmental effect and no feeling of guilt (Laestadius, 2015). Man-made meat may be the key to world hunger as cells can multiply endlessly, theoretically speaking, with very low costs. However, critics argue that In-Vitro meat is fundamentally unnatural. There may be hidden threats to nutrition deficiency, human health and the environment (Laestadius, 2015). The public acceptance of In-Vitro meat is still in question, but it is one possible solution to end suffering of animals in factory farms.

\subsection{Alternatives to Animal Experiments}

Choices of animal experiment alternatives are abundant. Cultured cells or tissues enable scientists to reproduce animal or human tissues in labs for testing. Computer simulation can create virtual human programs which could be more effective than animal testing: "virtual metabolism program can now predict drug effects in humans more accurately than animals can" (Arora, 2011). DNA chips have DNA fragments aligned on a piece of glass and researchers can experiment drugs on the chip. Microbiological substitution uses fungi instead of animals. Micro dosing allows new drugs to be experimented safely on humans using small quantities, but this method is very costly. Other alternatives include microfluidics, epidemiological surveys, plant-tissue based materials and a host of emerging new technologies (Arora, 2011).

These alternatives are already in use and help to reduce animals needed for experiments. They contribute to " $40 \%$ decrease in animal use" in Indian research institutions (Badyal, 2014). However, these methods can only reduce the number of animals sacrificed, but cannot completely eliminate animals used for research (Arora, 2011). They cannot provide a full replica of an animal or human body and the regulation agencies may not allow drugs to pass certification unless it has been tested on animals. But with the development of technology, maybe one day people can really be able to skip animal testing by using alternative experiments completely.

\subsection{Alternatives to Other Animal Mistreatments in Business}

For its value of education and conserving endangered species, zoos may not be eliminated for animal welfare. However, they can be less like caged exhibitions and more like replicas of animals' natural habitats, with enough space and humane care provided. This expectation requires zoos to move out of the cities, and use vast lands for both conservation of animals and environments together: "zoos will increasingly become more like national parks and wildlife reserves" (Keulartz, 2015). Instead of putting animals in cages, zoos can put people in secured vehicles while traveling through the habitat to get a thrilling view of nature.

There is no better alternative for entertainment animals other than to set them free. Animals have their own lives and natural behaviors and the only entertainment they can provide to people is a harmonious nature. Entertainment venues are likely to draw criticism from animal right activists and also from wildlife protectionist 
(Keulartz, 2015).Conserving endangered species may be a moral reason to confine animals, but entertainment is not an ethical reason to keep animals in captivity.

Pet breeding, as discussed before, is not ethical when there are more similar pets in the shelters waiting for a home. Pet breeding signifies human intervention into the evolutionary process and may cause genetic defects. Thus, the best solution for this problem is to stop the practice. As Fox (2010) noted, the "most ethical approach to dog ownership is to re-home a neutered rescue dog as opposed to buying or breeding a puppy." This solution requires specific laws and regulations, which could be hard to execute considering it is very easy to hide the breeding animals at home. However, people can reduce pet breeding by refusing to purchase pets from breeding mills.

\subsection{Legislation \& Media Coverage}

Legislation can be powerful, but currently animal mistreatment in business is more of an ethical issue than a legal one. As discussed earlier, in many countries, the animal protection laws exclude animals for farming, entertainment and research purposes. Therefore businesses comply with higher humane animal standards only voluntarily. After studying animal rights legislation in Sweden, United Kingdom, Germany and Spain, Lundmark et al (2014) concluded that "farmers affiliated to an organic standard or to a specific animal welfare standard were mainly motivated by ethical concerns." So, even when there are different levels of standards available for businesses to voluntarily participate, the bottom line is that the government will not prosecute conventional factories farm, zoos, research labs or breeders, as they are still legal. If governments really want to support animal welfare, they should prohibit these inhumane practices in producing animal products (Forsberg, 2011). However, future legislation enforcing humane animal treatments in all businesses can be expected if public awareness becomes high enough on this topic.

Media coverage on animal mistreatments in business can reveal the unknown reality of animal suffering to the public. Once people are aware of the issue, it is easier to call for actions to stop unethical animal treatments. In 2011, undercover journalists from BBC filmed a footage of Indonesian slaughterhouses which import cattle from Australia. One week after the footage was published the Australian government suspended the live export of cattle to Indonesia (Tiplady \&Phillips, 2015). The public reaction on the bloody scenes from slaughterhouses was emotionally intense and put pressure on the government to make quick changes. Whether banning cattle export can really cease animal cruelty remains uncertain; at least this case manifests the power of media. Therefore, one solution for animal cruelty is to encourage media to report more similar cases to educate the general public. The public can then exert influence on legislation, market demand for animal product, and the moral pressure put on businesses.

\section{Managerial Implications}

The ethical issue regarding animal mistreatment is not only a threat but an opportunity for businesses. The threat comes from social criticisms on animal abuse which may lead to decreased sales, especially with increased public awareness on animal welfare. A public survey showed that more consumers prefer sustainable and humane animal products: "animal welfare" and "nature" have become popular terms in public discussions and it shows increasing consumer awareness (Borkfelt et al, 2015). With this trend of public awareness, businesses practicing animal abuse may face more and more challenges from consumers, non-profit organizations, animal-friendly competitors and even the government in the future.

On the other hand, there are businesses opportunities associated with this trend on animal welfare. Just like the European labeling system discussed above, businesses can label their products as "from humane farms", "no animal testing", or "donate a percentage of sales to animal protection foundations". Customers may be willing to pay a premium for those socially responsible promises. Eventually, the increased sales and improved brand reputation may compensate for the higher costs of producing animal-friendly products. As Borkfelt et al (2015) noted, the "welfare quality brands" can really profit from the trend of "green" or "ethical" product preference". There are successful businesses that have already discovered this opportunity and acted on it. For example, McDonald's announced a plan to switch to the use of cage-free eggs in its breakfast products in late 2015 while Taco Bell became the first quick-service restaurant to launch a new menu of vegetarian options (Americas Food and Drink Insight2016).

\section{Conclusion}

Animal mistreatment in business is facing increasing criticism as it threatens a company's social responsibility, endangers the environment, and even erodes profits as consumers become more aware of this issue. As public concern increases, it is possible that more legislation will start enforcing animal welfare in commercial 
enterprises in the future. There are quite a few alternatives to conventional animal treatments which have potential business opportunities. Businesses should be aware of this trend and examine new humane alternatives in order to stay competitive in the market as well as to foster environmental sustainability. After all, helping animals is also helping human beings as it retains our humanity as the leader for all species.

\section{References}

Americas food and drink insight - August 2016. (2016). London: Business Monitor International. Retrieved from https://uwest.idm.oclc.org/login?url=http://search.proquest.com.uwest.idm.oclc.org/docview/1802756301?a ccountid $=25358$

Animal Welfare Act. (2016). United States Department of Agriculture. Retrieved from https://www.nal.usda.gov/awic/animal-welfare-act

Anonymous. Animal Rights Uncompromised: There's No Such Thing as a 'Responsible Breeder'. People for the Ethical Treatment of Animals. Retrieved from http://www.peta.org/about-peta/why-peta/responsible-breeders/

Arora, T., Mehta, A., Joshi, V., Mehta, K., Rathor, N., Mediratta, P., \& Sharma, K. (2011). Substitute of animals in drug research: An approach towards fulfillment of 4R's. Indian Journal of Pharmaceutical Sciences, 73(1), 1-6. https://doi.org/10.4103/0250-474X.89750

Badyal, D., \& Desai, C. (2014). Animal use in pharmacology education and research: The changing scenario. Indian Journal of Pharmacology, 46(3), 257-265. https://doi.org/10.4103/0253-7613.132153

Borkfelt, S., Kondrup, S., Röcklinsberg, H., Bjørkdahl, K., \& Gjerris, M. (2015).Closer to nature? A critical discussion of the marketing of "ethical" animal products. Journal of Agricultural and Environmental Ethics, 28(6), 1053-1073. https://doi.org/10.1007/s10806-015-9577-4

Cole, J. R., \& McCoskey, S. (2013). Does global meat consumption follow an environmental kuznets curve? Sustainability: Science, Practice, \& Policy, 9(2) Retrieved from

https://uwest.idm.oclc.org/login?url=http://search.proquest.com.uwest.idm.oclc.org/docview/1460161952?a ccountid $=25358$

Collins, F. (2015). Experiments on Animals: Overview. People for the Ethical Treatment of Animals. Retrieved from

http://www.peta.org/issues/animals-used-for-experimentation/animals-used-experimentation-factsheets/ani mal-experiments-overview/

Durham, S. (2011). Beef cattle: Improving production efficiency and meat quality. Agricultural Research, 59(1), 18-19. Retrieved from

https://uwest.idm.oclc.org/login?url=http://search.proquest.com/docview/849235871 ?accountid=25358

Farm forward: Against animal abuse in factory farming. (2010, 01).Natural Foods Merchandiser, 31, S12-S14. Retrieved from

https://uwest.idm.oclc.org/login?url=http://search.proquest.com.uwest.idm.oclc.org/docview/219562683?ac countid $=25358$

Forsberg, E. (2011). Inspiring respect for animals through the law? current development in the norwegian animal welfare legislation. Journal of Agricultural and Environmental Ethics, 24(4), 351-366. https://doi.org/10.1007/s10806-010-9263-5

Fox, M. (2010). Taking dogs seriously? Law, Culture and the Humanities, 6(1), 37-55.

Goodale, G. (2015). From ringling bros. to sea world, Americans stand up for animals. The Christian Science Monitor Retrieved from

https://uwest.idm.oclc.org/login?url=http://search.proquest.com.uwest.idm.oclc.org/docview/1662664442?a c countid $=25358$

Green, L., Costello, L., \& Dare, J. (2010).Veganism, health expectancy, and the communication of sustainability. Australian Journal of Communication, 37(3), 51-72. Retrieved from https://uwest.idm.oclc.org/login?url=http://search.proquest.com.uwest.idm.oclc.org/docview/884025488?ac countid $=25358$

Greger, M. (2011). Transgenesis in animal agriculture: Addressing animal health and welfare concerns. Journal of Agricultural and Environmental Ethics, 24(5), 451-472. https://doi.org/10.1007/s10806-010-9261-7

Heerwagen, L. R., Mørkbak, M. R., Denver, S., Sandøe, P., \& Christensen, T. (2015). The role of quality labels 
in market-driven animal welfare. Journal of Agricultural and Environmental Ethics, 28(1), 67-84. https://doi.org/10.1007/s10806-014-9521-z

Hitch, D. (2015). Nonhuman species looking for justice. Telegram \& Gazette. Retrieved from https://uwest.idm.oclc.org/login?url=http://search.proquest.com.uwest.idm.oclc.org/docview/1676212227?a c countid $=25358$

Kesmodel, D. (2015). Flap over eggs: Whether to go 'cage-free' --- as states ban tight confinement of hens, farmers weigh the cost of open layouts against simply larger coops. Wall Street Journal Retrieved from https://uwest.idm.oclc.org/login?url=http://search.proquest.com/docview/1663486902?accountid=25358

Keulartz, J. (2015). Captivity for conservation? zoos at a crossroads. Journal of Agricultural and Environmental Ethics, 28(2), 335-351. https://doi.org/10.1007/s 10806-015-9537-z

Kuwahara, S. S. (2011). Rats and mice exemption from animal welfare act. Journal of GXP Compliance, 15(1), 65-69.

Retrieved

from https://uwest.idm.oclc.org/login?url=http://search.proquest.com/docview/862155724 ?accountid=25358

Laestadius, L. I. (2015). Public perceptions of the ethics of in-vitro meat: Determining an appropriate course of action. Journal of Agricultural and Environmental Ethics, 28(5), 991-1009. https://doi.org/10.1007/s10806-015-9573-8

Last, J. V. (2012). How killer whales become killers. Wall Street Journal (Online) Retrieved from https://uwest.idm.oclc.org/login?url=http://search.proquest.com.uwest.idm.oclc.org/docview/1030969956?a c countid $=25358$

Lundmark, F., Berg, C., Schmid, O., Behdadi, D., \& Röcklinsberg, H. (2014).Intentions and values in animal welfare legislation and standards. Journal of Agricultural and Environmental Ethics, 27(6), 991-1017. https://doi.org/10.1007/s10806-014-9512-0

Macwilliams, J. (2013) Milk Of Human Kindness Denied To Dairy Cows. Walls Street Journal. Retrieved from http://www.forbes.com/sites/jamesmc williams/2013/10/25/milk-of-human-kindness-denied-to-dairy-cows/\# $37 \mathrm{~d} 0 \mathrm{db} 3261 \mathrm{~d} 9$

Malone, T., \& Lusk, J. L. (2016). Putting the chicken before the egg price: An ex post analysis of california's battery cage ban. Journal of Agricultural and Resource Economics, 41(3), 518-532. Retrieved from https://uwest.idm.oclc.org/login?url=http://search.proquest.com/docview/1826924787?accountid=25358

Meat products manufacture - quarterly update 1/24/2011. (2011). Austin: Hoover's Inc. Retrieved from https://uwest.idm.oclc.org/login?url=http://search.proquest.com.uwest.idm.oclc.org/docview/847137383?ac countid $=25358$

Mitrovic, S., Dermanovic, V., Radivojevic, M., Rajic, Z., Zivkovic, D., Ostojic, D., \& Filipovic, N. (2010). The influence of population density and duration of breeding on broiler chickens productivity and profitability. African Journal of Biotechnology, 9(28), 4486-4490.

Plavsic, M. (2016).An integrated approach to ensure the viral safety of biotherapeutics. Biopharm International, 29(5), 40-45. Retrieved from

https://uwest.idm.oclc.org/login?url=http://search.proquest.com.uwest.idm.oclc.org/docview/1792211208?a c countid $=25358$

Pluhar, E. B. (2010). Meat and morality: Alternatives to factory farming. Journal of Agricultural and Environmental Ethics, 23(5), 455-468. https://doi.org/10.1007/s10806-009-9226-x

Rossi, J., \& Garner, S. A. (2014). Industrial farm animal production: Acomprehensive moral critique. Journal of Agricultural and Environmental Ethics, 27(3), 479-522. https://doi.org/10.1007/s10806-014-9497-8

Saja, K. (2013). The moral footprint of animal products. Agriculture and Human Values, 30(2), 193-202. https://doi.org/10.1007/s10460-012-9402-x

Sarkar, J. (2014). KFC creates a veg menu for india food. The Economic Times (Online) Retrieved from https://uwest.idm.oclc.org/login?url=http://search.proquest.com.uwest.idm.oclc.org/docview/1514475019?a c countid $=25358$

See, A. W. (2013). Animal protection laws of Singapore and Malaysia. Singapore Journal of Legal Studies, 125-157. Retrieved from https://uwest.idm.oclc.org/login?url=http://search.proquest.com.uwest.idm.oclc.org/docview/1448255706?a c countid $=25358$ 
Shani, A., \&Pizam, A. (2010). The role of animal-based attractions in ecological sustainability. Worldwide Hospitality and Tourism Themes, 2(3), 281-298. https://doi.org/10.1108/17554211011052212

Tiplady, C. M., Walsh, D. B., \& Phillips, C. J. (2015). Ethical issues concerning the public viewing of media broadcasts of animal cruelty. Journal of Agricultural and Environmental Ethics, 28(4), 635-645. https://doi.org/10.1007/s10806-015-9547-x

Vaarst, M., \& Alrøe, H. F. (2012). Concepts of animal health and welfare in organic livestock systems. Journal of Agricultural and Environmental Ethics, 25(3),333-347. https://doi.org/10.1007/s10806-011-9314-6

Walker, R. L., \& King, N. M. P. (2011). Biodefense research and the U.S. regulatory structure whither nonhuman primate moral standing? Kennedy Institute of Ethics Journal, 21(3), 277-310. https://doi.org/10.1353/ken.2011.0012

Zur, I., \& Klöckner, C. A. (2014). Individual motivations for limiting meat consumption. British Food Journal, 116(4), 629-642. https://doi.org/10.1108/BFJ-08-2012-0193

\section{Copyrights}

Copyright for this article is retained by the author(s), with first publication rights granted to the journal.

This is an open-access article distributed under the terms and conditions of the Creative Commons Attribution license (http://creativecommons.org/licenses/by/4.0/). 